\title{
Penentuan Kelas Pemanen Kelapa Sawit di PT Dwiwira Lestari Jaya Estate
}

\author{
Nabila Maykurnia \\ Pengelolaan Perkebunan, \\ Politeknik Pertanian Negeri \\ Samarinda, \\ Samarinda 75131 \\ nabilamaykurnia@gmail.com
}

\author{
Faradilla \\ Budidaya Tanaman Perkebunan, \\ Politeknik Pertanian Negeri \\ Samarinda, \\ Samarinda 75131 \\ Dillafara@gmail.com
}

\author{
Rossy Mirasari \\ Pengelolaan Perkebunan, \\ Politeknik Pertanian Negeri \\ Samarinda, \\ Samarinda 75131 \\ rossymalik678@gmail.com
}

\begin{abstract}
Abstrak - Penelitian ini dilatarbelakangi oleh pentingnya menentukan kriteria kelas pemanen yang merupakan penilaian yang dilakukan ke masing masing pemanen, agar pemanen berkompetisi secara sehat dalam meningkatkan produktivitas, kehadiran dan tidak memanen buah mentah serta menjaga tanamaan dan melakukan pekerjaan yang benar. Sehingga adanya penilaian ke pemanen ini juga diharapkan mandor panen akan secara mendetail lagi memetakan anggotanya mana yang bagus dan mana yang perlu pengarahan. Penelitian ini bertujuan untuk mengetahui kriteria kelas pemanen kelapa sawit berdasarkan nilai-nilai produktivitas, kehadiran dan panen buah mentah di PT. Dwiwira Lestari Jaya (DLJ) Estate 1 Kabupaten Berau Provinsi Kalimantan Timur. Penelitian ini menggunakan metode deskriptif kualitatif, dengan mengambil data primer berupa observasi, data lapangan, dokumentasi, wawancara, dan data sekunder berupa dokumen perusahaan. Responden diambil dengan metode sampling jenuh, Hasil penelitian menunjukkan bahwa sebagian besar $(46,7 \%)$ masuk dalam kategori $\mathrm{C}$ yang dimana kategori ini hanya tergolong cukup atau merupakan kelas terendah di antara kelas lainnya, kemudian $33.3 \%$ yang masuk dalam kategori B yaitu tergolong baik dan hanya $20 \%$ yang masuk kategori A yaitu kelas sangat baik. Hasil ini berdasarkan penilaian produktivitas, kehadiran dan panen buah mentah
\end{abstract}

Kata Kunci-Kelas Pemanen Kelapa Sawit, Kriteria, Produktivitas, Kehadiran, Panen Buah Mentah

\section{PENDAHULUAN}

Kelapa sawit yang merupakan salah satu komoditas perkebunan unggulan di Indonesia. Tanaman yang produk utamanya terdiri dari minyak sawit (Crude Palm Oil) dan minyak inti sawit ini memiliki nilai ekonomis tinggi dan menjadi salah satu penyumbang devisa negara yang terbesar dibandingkan dengan komoditas perkebunan lainnya. Hingga saat ini kelapa sawit telah diusahakan dalam bentuk perkebunan dan pabrik pengolahan kelapa sawit hingga menjadi minyak dan produk turunannya. Dengan demikian, kelapa sawit memiliki arti penting bagi perekonomian di Indonesia (Fauzi, 2012).

Melihat pentingnya tanaman kelapa sawit dimasa ini dan masa yang akan datang, seiring dengan meningkatnya kebutuhan penduduk dunia akan minyak sawit, maka perlu dipikirkan usaha peningkatan produksi kelapa sawit secara tepat agar sasaran yang diinginkan dapat tercapai (Purwanto, 2016).

Produktivitas kelapa sawit antara lain ditentukan oleh kesesuaian syarat tumbuh dan teknik budidaya yang diterapkan dan potensi produksi yang tinggi tidak ada artinya jika eksploitasi hasil tidak dilakukan secara optimal. Karena itu kegiatan panen sangat menunjang produktivitas kelapa sawit.

Panen merupakan subsistem produksi di perkebunan kelapa sawit yang menghubungkan kebun dan pabrik kelapa sawit (PKS). Kegiatannya meliputi memotong tandan buah segar (TBS), meletakkan tandan buah segar (TBS) di piringan, dan mengumpulkan tandan buah segar (TBS) yang telah dipotong serta buah yang memberondol ke tempat pengumpulan hasil (TPH).

Banyak hal yang harus diperhatikan dalam upaya meningkatkan performa panen. Yang terpenting tentunya hasil panen TBS yang baik berdasarkan kualitas dan kuantitas salah satunya ditentukan oleh kinerja dan kemampuan pemanen. Selain itu kebijakan dalam mengurus pemanen juga perlu diperhatikan agar bisa memperbaiki, mempertahankan, atau bahkan meningkatkan kinerja pemanen

Kinerja pemanen bisa dilihat berdasarkan penilaian kelas pemanen. Menurut Sulistiyo, dkk (2016) kelas pemanen adalah tingkatan bagi tiap-tiap pemanen atau prestasi pemanen untuk mendapatkan penghargaan berupa uang sesuai dengan persentasi kelas yang ditetapkan.

Kelas pemanen merupakan penilaian yang dilakukan terhadap masing-masing pemanen, agar pemanen dapat berkompetisi secara sehat dalam mencapai produktivitas panen baik secara kuantitas maupun kualitas. Hasil penilaian dari kelas pemanen juga bisa dijadikan dasar untuk menindak pemanen yang bermasalah, serta untuk mencari dan mempertahankan pemanen yang berkualitas. Pengelompokan pemanen berdasarkan faktor tertentu juga terbukti mampu memicu keinginan dari dalam pemanen untuk maju.

Penilaian dapat dilakukan oleh mandor panen, mandor satu, asisten afdeling, atau orang khusus dari pabrik (grading) yang kemudian akan dihitung oleh krani afdeling. Kelas pemanen bisa dengan kriteria A,B,C atau baik sekali, baik, dan kurang baik, tergantung ketentuan perusahaan. Penilaian dapat dilakukan setiap hari, atau 
setiap minggu, atau setiap bulan. Dengan demikian diharapkan ada usaha yang baik bagi pemanen untuk melakukan pekerjaan secara benar. Adanya penilaian ini juga diharapkan mandor secara terperinci bisa memetakan anggotanya mana yang bagus dan mana yang perlu pengarahan dan sosialisasi untuk melakukan kegiatan panen dengan lebih baik lagi. Selain itu bisa dilihat mana pemanen yang mengerti dan yang belum mengerti terhadap apa yang diarahkan dan disosialisasikan oleh pimpinan (Anonim, 2014)

Menurut Sairin (1990) klasifikasi hasil panen dibedakan menjadi 3 yaitu: kelas A, B dan C. Kelas A diberikan kepada pemanen yang hanya melakukan kesalahan panen kurang dari 15, pemanen yang melakukan 15-30 kesalahan akan mendapat kelas B dan untuk pemanen yang melakukan kesalahan lebih dari 30 akan mendapatkan kelas panen $\mathrm{C}$.

Penentuan kelas pemanen dapat ditentukan oleh tiga kriteria diantaranya produktivitas, kehadiran dan panen buah mentah. Produktivitas merupakan hal yang utama dalam menentukan kelas pemanen, nilai ini juga sebagai pemicu karyawan agar selalu mendapatkan produktivitas sesuai basis panen yang ditentukan oleh perusahaan, bahkan lebih dari basis agar mendapatkan nilai tinggi pada kriteria produktivitas sehingga dapat menaikkan kelas pemanen. Produktivitas dinilai dengan total output (janjang) dalam sebulan, total basis dalam sebulan (basis per hari dikali hari kerja aktual). Janjang panen hari minggu atau libur tidak dimasukkan dalam penilaian.

Kehadiran merupakan salah satu kriteria kelas pemanen, untuk menaikkan kelas panen, karyawan panen harus memiliki nilai kehadiran yang cukup bahkan direncanakan pada rencana kerja harian $(\mathrm{RKH})$ karyawan hadir semua. Perhitungan nilai kehadiran, hari kerja aktual dalam sebulan, hari kerja efektif dalam sebulan, nilai-nilai tersebut yang akan dihitungan untuk mengetahui total nilai kehadiran pemanen.

Panen buah mentah, dalam penilaian ini pemanen yang memanen buah mentah akan mendapatan nilai minus, bahkan akan mendapatkan denda apabila pada saat grading ditemukan buah mentah di TPH.

Maka dari itu untuk memacu agar pelaksanaan panen mendapatkan hasil panen yang tinggi harus ditentukan kelas panen. Berdasarkan uraian latar belakang diatas maka penulis melakukan penelitian berjudul: Penentuan kelas pemanen kelapa sawit.

Adapun rumusan masalah pada penelitian ini adalah terdapat karyawan panen yang melakukan panen buah mentah, adanya karyawan panen yang tidak memenuhi basis dan adapun karyawan panen yang tidak hadir atau memenuhi hari kerja efektif.

Penelitian ini mempunyai batasan masalah hanya pada nilai-nilai produktivitas, kehadiran dan panen buah mentah terhadap kriteria kelas pemanen. Penelitian ini terbatas hanya mencakup 1 afdeling.

Adapun tujuan dari penelitian ini adalah untuk mengetahui kriteria kelas pemanen kelapa sawit berdasarkan nilai-nilai produktivitas, kehadiran dan panen buah mentah di lapangan. Dan dari penelitian ini diharapkan dapat memberikan informasi, manfaat untuk ilmu pengetahuan, wawasan serta masukan bagi perusahaan mengenai kriteria kelas pemanen dan berdasarkan nilai produktivitas, kehadiran dan panen buah mentah.

\section{METODOLOGI}

\section{Tempat dan Waktu Penelitian}

Penelitian dilaksanakan pada perkebunan kelapa sawit PT. Dwiwira Lestari Jaya (DLJ), Afdeling Echo, Kecamatan Biatan. Kampung Biatan Ilir Kabupaten Berau, Provinsi Kalimantan Timur. Penelitian ini dilaksanakan selama 1 bulan, terhitung mulai tanggal 1 Oktober sampai 31 Oktober 2020, meliputi observasi lapangan dan pengambilan data.

\section{Alat dan Bahan}

Alat yang digunakan dalam penelitian ini adalah laptop, program komputer Microsoft Office Word, Microsoft Excel, alat tulis, dan kamera.

Bahan yang digunakan dalam penelitian ini adalah form pengisian data, dokumen/arsip perusahaan, dan literatur/pustaka.

\section{Metode Penelitian}

Responden sebagai sumber data dan informasi diambil dari seluruh karyawan panen di afdeling Echo PT. DLJ, sejumlah 30 orang.

Dalam penelitian ini digunakan pengumpulan data primer dan sekunder dengan cara sebagai berikut :

a. Data primer berupa penelitian di lapangan :

- Wawancara

Wawancara dilakukan dengan cara tanya jawab secara langsung kepada asisten, mandor atau bagian administrasi kebun, mengenai pelaksanaan kegiatan pemanenan pada unit kerja (afdeling) yang dikelola.

- Pengamatan Lapangan

Pengamatan lapangan dilakukan secara langsung di lapangan dengan cara melakukan pengambilan data melalui kegiatan di lapangan berupa kondisi lapangan, proses kegiatan kerja dan hasil kegiatan.

- Dokumentasi

Pengambilan gambar mengenai pelaksanaan kegiatan pemanenan yang dilakukan di lapangan guna menunjang data penelitian.

\section{b. Data Sekunder}

Data sekunder didapatkan dari dokumen perusahaan dengan cara mengumpulkan dan menganalisis dokumendokumen/arsip perusahaan yang berhubungan dengan sistem ancak panen dan data lain seperti SOP perusahaan, basis panen, dan lain-lain, untuk mendukung penelitian yang terdapat pada perusahaan khususnya pada afdeling tempat penelitian. Selain itu data sekunder juga didapatkan dari studi pustaka yang dilakukan dengan cara membaca dan mempelajari literatur-literatur yang berkaitan dengan masalah yang sedang diteliti.

\section{Prosedur Penelitian}

Prosedur penelitian adalah sebagai berikut : 
a. Persiapan

Sebelum pelaksanaan penelitian, terlebih dahulu melakukan persiapan alat dan bahan yang akan dipergunakan serta survei lokasi untuk menentukan lokasi afdeling

b. Pelaksanaan

Pengambilan data dilakukan terhadap responden karyawan panen, mandor, administrasi kebun, dan asisten afdeling

c. Pengamatan

Parameter pengamatan meliputi deskripsi responden dan deskripsi variabel.

Deskripsi responden berisi tentang data karakteristik responden meliputi usia dan lama bekerja.

Deskripsi variabel digunakan untuk penentuan kriteria kelas pemanen. Variabel yang diamati meliputi produktivitas pemanen, kehadiran dan panen buah mentah.

Kelas pemanen dibagi menjadi tiga kelas, yaitu : kelas A nilai $\geq 90$, kelas $\mathrm{B}$ nilai $70-<90$ dan kelas $\mathrm{C}$ dengan nilai $<70$. Untuk penentuan nilai produktivitas, kehadiran, dan panen buah mentah, menggunakan perhitungan sebagai berikut:

- Produktivitas = Output Sebulan / $($ (Hari Biasa Basis x Hari Biasa Aktual) + (Jumat Basis x Jumat Aktual))

- Kehadiran $=$ Total Hari Kerja $/$ Hari Kerja Efektif x $100 \%$

- Panen Buah Mentah = Janjang Buah Mentah / (Nilai Produktivitas x Nilai Kehadiran) x 100\%

\section{A. Hasil}

\section{HASIL DAN PEMBAHASAN}

\section{Karakteristik responden}

Responden dalam penelitian ini memiliki karakteristik yang berbeda antara satu sama lain. Berikut ini merupakan data karakteristik responden yang disusun berdasarkan usia dan lama bekerja.

a. Responden Berdasarkan Usia

Hasil pengambilan data mengenai identitas responden khususnya usia dapat dilihat pada tabel 1 berikut ini:

Tabel 1. Kondisi Responden Berdasarkan Usia

\begin{tabular}{|l|l|l|l|}
\hline No. & Usia (Tahun) & Jumlah & Persentase \\
\hline 1. & $20-30$ & 20 & 66,6 \\
\hline 2. & $31-40$ & 5 & 16,7 \\
\hline 3. & $41-50$ & 5 & 16.7 \\
\hline Total & 30 & 100 \\
\hline
\end{tabular}

Sumber : Olahan penulis (2021)

Berdasarkan data tabel 1 di atas karakteristik responden menurut usia responden dengan rentang 20-30 tahun adalah dominan yaitu $66,6 \%$.

b. Responden berdasarkan Lama Bekerja

Tabel 2. Reponden Berdasarkan Lama Bekerja

\begin{tabular}{|l|l|l|l|}
\hline No. & $\begin{array}{l}\text { Lama Bekerja } \\
(\text { Tahun })\end{array}$ & Jumlah & Persentase \\
\hline 1. & $<1$ & 12 & 40 \\
\hline 2. & $1-2$ & 15 & 50 \\
\hline 3. & $3-5$ & 0 & 0 \\
\hline
\end{tabular}

\begin{tabular}{|l|l|l|l|}
\hline 4. & $>5$ & 3 & 10 \\
\hline Total & 30 & 100 \\
\hline
\end{tabular}

Sumber : Olahan penulis (2021)

Berdasarkan data tabel 2 di atas karakteristik responden lama bekerja dengan rentang1-2 tahun adalah dominan dengan nilai persentase yaitu $50 \%$.

\section{Kriteria kelas pemanen}

Dalam penelitian ini kriteria kelas pemanen ditentukan oleh nilaii produktivitas, kehadiran dan panen buah mentah.

Tabel 3. Nilai Produktivitas, Kehadiran Dan Panen Buah Mentah

\begin{tabular}{|r|l|l|l|}
\hline Kelas & Produktivitas & Kehadiran & $\begin{array}{l}\text { Panen } \\
\text { Buah Mentah }\end{array}$ \\
\hline A & $70(33,3 \%)$ & $30(36,7 \%)$ & $0(40 \%)$ \\
\hline B & $50(60 \%)$ & $20(10 \%)$ & $-5(23,3 \%)$ \\
\hline C & $30(6,7 \%)$ & $10(53,3 \%)$ & $-10(36,7 \%)$ \\
\hline \multicolumn{4}{|c|}{ Sumber : Olahan penulis $(2021)$}
\end{tabular}

Berdasarkan data tabel 3 dapat dijelaskan bahwa produktivitas dengan nilai 70 sebesar $(33,3 \%)$, nilai 50 dengan nilai persentase $(60 \%)$ dan untuk nilai 30 sebesar $(6,7 \%)$. Kehadiran dengan nilai 30 sebanyak $(36,7 \%)$, nilai kehadira 20 sebanyak $(10 \%)$ dan untuk nilai 10 dengan nilai persentase $(53,3 \%)$. Sebanyak $(40 \%)$ dengan nilai buah mentah 0 , dan nilai -5 sebanyak $(23,3 \%)$ kemudian untuk nilai buah mentah -10 terdapat $(36,7 \%)$.

Tabel 4. Kriteria kelas pemanen

\begin{tabular}{|c|c|c|c|c|}
\hline No & $\begin{array}{l}\text { Kelas } \\
\text { Pemanen }\end{array}$ & $\begin{array}{l}\text { Nilai } \\
\text { Total }\end{array}$ & Jumlah & Persentase \\
\hline 1 & A & $\geq 90$ & 6 & $20 . \%$ \\
\hline 2 & $\mathrm{~B}$ & $70 \leq 90$ & 10 & $33.3 \%$ \\
\hline 3 & $\mathrm{C}$ & $<70$ & 14 & $46.7 \%$ \\
\hline \multicolumn{3}{|c|}{ Total } & 30 & $100.0 \%$ \\
\hline
\end{tabular}

Sumber : Olahan penulis (2021)

Berdasarkan data tabel 4 mengenai kriteria kelas pemanen, dari 30 responden dengan nilai total yang paling dominan adalah $<70$ sebanyak 14 responden dengan persentase $(46,7 \%)$, dan selanjutnya nilai total $70-<90$ dengan jumlah responden $10(33,3 \%)$ pada urutan terakhir dengan nilai total $\geq 90$ sebanyak 6 reponden dengan nilai persentase $(20 \%)$.

\section{B. Pembahasan}

\section{Karakteristik responden}

a) Usia

Karakteristik responden sangat penting diketahui dalam suatu penelitian, jika dilihat dari faktor usia maka dapat dijelaskan bahwa rata-rata umur karyawan panen adalah $20-30$ tahun $(66,6 \%)$ yang berarti didominasi oleh usia yang produktif dalam hal bekerja. Hal ini menunjukkan pemanen pada Afdeling Echo memasuki usia produktif dalam melaksanakan kegiatan panen, 
sehingga pemanen mampu menghasilkan produktivitas yang tinggi untuk prusahaan.

Menurut Mahendra (2014) salah satu faktor yang mempengaruhi nilai produktivitas adalah faktor usia. Usia yang masih muda dalam masa produktif adalah 2030 tahun. Biasanya yang mempunyai tingkat tenaga atau fisik lebih dibandingkan tenaga kerja yang sudah berusia tua yang disebabkan fisik yang dimiliki menjadi lemah dan terbatas. Simamora dkk., (2016) meyatakan bahwa pekerjaan memanen TBS tergolong kedalam pekerjaan yang berat dan memerlukan fisik yang kuat dan baik, sehingga banyak diisii oleh kelompok usia yang tergolong usia produktif

b) Lama Bekerja

Dari aspek lama bekerja dapat dijelaskan bawah lama bekerja yang paling dominan yaitu 1-2 tahun (50\%). Kedua aspek ini sangat penting karena dengan usia yang produktif dan memiliki lama bekerja yang cukup lama dapat menunjang keberhasilan kerja sekaligus juga dapat dengan mudah memahami kegiatan panen yang merupakan bagian penting untuk mengetahui kriteria matang panen agar tidak memanen buah mentah.

Dalam upaya meningkat nilai-nilai kriteria kelas pemanen, lama bekerja sangat diperlukan terutama pada kriteria: panen buah mentah. Lama bekerja mencerminkan tingkat penguasaan pengetahuan dalam memanen TBS, seseorang karyawan yang memiliki masa berkerja cukup lama pasti telah paham kriteria buah yang wajib dipanen dan tidak boleh dipanen sesuai dengan SOP Perusahaan.

Sebagaimana dinyatakan oleh Septi dan Iskandar (2016) bahawa lama bekerja akan mempengaruhi tingkat keterampilan dan pengalaman pekerja. Dengan bertambhanya lama bekerja karyawan akan terjadi peningkatan kinerja sehingga produktivitas kerja akan meningkat.

Menurut Bindrianes dkk., (2017) bahwa lama bekerja mencerminkan pengalaman yang dimiliki pemanen dalam memananen Tandan Buah Segar (TBS). Pemanen yang sudah lama bekerja dapat dipastikan lebih mengenal seluk beluk permasalahan yang dihadapi, sehingga lebih mampu untuk mengatasinya permasalah tersebut. Pekerjaan yang sudah berulang-ulang atau sering dilakukan dilakukan dalam jangka yang lama akan membuat seseorang lebih cekatan dan terampil dalam melaksanakan tugas yang diberikan dan sesuai dengan peraturan.

\section{Kriteria kelas pemanen}

Hasil penelitian yang penulis dapatkan sesuai pada tabel 3 dapat dijelaskan bahwa kriteria kelas pemanen berdasarkan: produktivitas dengan nilai produktivitas yaitu 70, 50 dan 30. Nilai-nilai ini dipengaruhi oleh total output (janjang) sebulan pemanen tanpa menghitung janjang panen hari minggu atau libur. Apabila pemanen ingin memasuki kriteria nilai yang baik untuk produktivitas maka pemanen harus mengumpulkan atau memanen buah (janjang) sebanyak mungkin setiap harinya sesuai dengan kemampuan masing-masing pemanen.
Menurut Simamora dkk., (2016) produktivitas tenaga kerja pemanen dapat dinilai berdasarkan beberapa hal: total hasil panen kelapa sawit yang diperoleh tenaga kerja, dibandingkan dengan basis panen kelapa sawit yang telah ditetapkan oleh pihak perusahaan.

Produktivitas merupakan hal yang utama dalam menentukan kelas pemanen, nilai ini juga sebagai pemicu karyawan agar selalu mendapatkan produktivitas sesuai basisi bahkan lebih agar mendapatkan nilai tinggi pada kriteria produktivitas sehingga dapat menaikkan kelas pemanen. Basis pemanen di PT. DLJ khususnya Afdeling Echo satu harinya sebanyak 67 janjang untuk hari biasa, sedangkan untuk basis hari jumat 48 janjang. Basis atau target ini ditentukan berdasarkan BJR masingmasing Afdeling. Untuk Afdeling Echo meliki berat janjang rata-rata yaitu $19 \mathrm{Kg}$.

Berdasarkan hasil penelitian yang penulis dapatkan sesuai pada tabel 3 dapat dijelaskan bahwa kriteria kelas pemanen berdasarkan: kehadiran dengan ketentuan nilai 30 memiliki tingkat kehadiran $\geq 95 \%$, nilai 20 dengan persentase $90-<95 \%$ dan nilai 10 mendapatkan nilai $<90 \%$. Nilai-nilai dan persentase tersebut ditentukan oleh total hari kerja pemanen dalam hari kerja efektif selama satu sebulan, kehadiran pemanen dibedakan antara hari biasa dan hari jumat. Dalam penelitian ini kehadiran sangat berperan penting untuk mencapai kelas pemanen, berdasarkan hasil penelitian bahwa tingkat kehadiran dibawah $40 \%$ merupakan persentase tertinggi, hal ini meyebabkan nilai kehadiran maupun produktivitas pemanen menjadi rendah. Jika ingin mendapatkan nilai kehadiran tinggi maka dalam satu bulan pemanen minimal memiliki kehadiran 25 hari kerja dari 26 hari efektif kerja.

Menurut Simonna (2009) tingkat kehadiran karyawan merupakan bukti atau bentuk karyawan hadir atau tidak hadir dalam bekerja disuatu perusahaan atau komponen perusahaan itu sendiri yang berisi data kehadiran yang disusun sedemikian rupa yang akan dipergunakan apabila diperlukan oleh pihak terkait.

Kehadiran merupakan salah satu kriteria kelas pemanen, untuk menaikkan kelas panen, karyawan panen harus memiliki nilai kehadiran yang cukup bahkan direncakan pada rencana kerja harian $(\mathrm{RKH})$ karyawan hadir semua.

Sedangkan untuk kriteria pemanen berdasarkan panen buah mentah sesuai pada tabel 3 menunjukkan bahwa persentase panen buah mentah dengan persentase $0 \%$ maka nilainya 0 , persentase $\geq 0 \%-0,1 \%$ nilainya -5 dan untuk persentase $\geq 0,1 \%$ maka nilainya -10 . Nilai pada kriteria ini dipengaruhi oleh pemanen yang melakukan panen buah mentah, memanen buah mentah akan mendapatan nilai minus, bahkan akan mendapatkan denda apabila pada saat grading ditemukan buah mentah di TPH.

Menurut Nugraha dkk., (2018) pemanen harus jeli dalam melihat buah yang siap panen, agar buah yang dipanen benar-benar buah yang telah masak, kesalahan pemanen yang dapat menurunkan kualitas panen salah satunya adalah memanen buah mentah. 
Panen buah mentah biasanya terjadi apabila karyawan belum paham betul kriteria buah siap panen dalam belum siap panen adapun penyebab lainnya dari karyawan memanen buah mentah yaitu karyawan belum memenuhi basis harian (hari biasa maupun hari jumat) atau target perusahaan namun dan terdesak untuk selalu memenuhi basis sedangkan rotasi panen sangat kecil dan nilai AKP rendah. Hal lain yang menyebabkan karyawan panen memanen buah mentah yaitu: pengawasan yang kurang ketat dari mandor, kurangnya pengetahuan karyawan panen tetang pemanenan sehingga diperlukannya pemberian pelatihan.

Berdasarkan hasil penelitian pada tabel 4 kriteria kelas pemanen di Afdeling Echo menyatakan bahwa kelas pemanen dengan kelas paling tinggi yaitu A terdapat 6 responden dengan persentase $20 \%$ untuk kelas B 10 responden dengan nilai persentase $33,3 \%$ namun untuk kelas $C$ terdapat 14 responden dengan persentase $46,7 \%$. Hal ini menyatakan bahwa kelas pemanen pada afdeling yang diteliti masih kurang baik dikarenakan kelas yang paling dominan respondennya ialah kelas $\mathrm{C}$ dengan responden sebanyak 14 orang.

Adanya penilaian terhadap pemanen ini juga diharapkan mandor panen akan secara mendetail lagi dalam pengawasan anggotanya dan melihat mana anggota yang telah benar-benar paham dan mana anggotanya yang belum paham terhadap apa yang telah disampaikan oleh pimpinan setiap paginya.

Penentuan kelas pemanen ini juga bisa digunakan sebagai salah satu faktor untuk menentukan besarnya premi yang diberikan kepada karyawan panen yang dimana nilai dan kelas pemanen dapat berubah setiap bulannya. Berdasarkan hasil dari beberapa penelitian sebelumnya tentang faktor yang mempengaruhi produktivitas karyawan panen, maka premi ini merupakan salah satu faktor yang berpengaruh nyata. Menurut Nugraha (2019), faktor premi secara parsial berpengaruh nyata terhadap produktivitas karyawan panen. Oleh karena itu dengan adanya penentuan kelas pemanen yang menjadi dasar dalam menentukan besarnya premi yang bisa diterima oleh karyawan panen, maka diharapkan dapat meningkatkan produktivitas karyawan panen, baik secara kualitas maupun kuantitas dari tandan buah segar.

\section{KESIMPULAN}

Berdasarkan hasil penenlitian dan pembahasan yang telah penulis dapatkan maka dapat ditarik suatu kesimpulan bahwa diketahui pemanen di PT. Dwiwira Lestari Jaya Afdeling Echo dengan kategori kelas A hanya sebesar $20 \%$ dari jumlah pemanen yang ada, selanjutnya adalah kelas B sebesar 33.3\%, kelas C $46.7 \%$ yang berarti kelas pemanen di Afdeling Echo adalah mayoritas rendah.

\section{DAFTAR PUSTAKA}

Afifah. S. N. dan Lubis. S. 2016. Faktor Penentu Tenaga Kerja Pnen Kelapa Sawit, Kalimantan Timur. Departemen Agronomi dan Hortikultura, Fakultas Pertanian, Institut Pertanian Bogor. Bul.Agrohorti 4(2): 215-223.

Astuti, Murdwi dkk. 2014. Pedoman Budidaya Kelapa Sawit (Elais Guenensis) Yang Baik. Jakarta: Direktorat Jendral Perkebunan Kementrian Pertanian.

Bindrianes S., Kemala, N., dan Busyra, R. G. 2017. Produktivitas Tenaga Kerja Panen Kelapa Sawit dan Faktor-Faktor Yang Mempengaruhi Pada Unit Usaha Batanghari di PTPN VI Jambi. Jurnal Agribisnis Sumatra Utara, 74-85. (diunduhan 20 Maret 2021)

Fauzi,Y. dkk. 2012. Kelapa Sawit. Budi Daya, Pemanfaatan Hasil dan Limbah, Analisis Usaha dan Pemasaran. Jakarta: Penebar Swadaya.

Nugraha, D.P., 2019. Analisis Faktor Yang Mempengaruhi Produktivitas Kerja Karyawan Pemanen Kelapa Sawit di PTPN II. Skripsi Universitas Sumatera Utara.

Nugraha, M,A,S dan Santi, I, S. 2018. Pengaruh Kualitas Panen Terhadap Losses Di perkebunan Kelapa Sawit di PT Wansawit Subur Sumber Lestari 2. Jurnal Agromast. Vol.3,No.1.

Nurhakim, Y. I. 2014. Perkebunan Kelapa Sawit Cepat Panen. Jawa Barat: Sukma Jaya Depok.

Pardamean, M. 2017. Kupas Tuntas Agribisnis Kelapa Sawit. Jakarta: Penebar Swadaya.

Purwanto. 2016. Tips Sukses Usaha dan Berkebun Sawit. Depok: Palapa.

Setiawan, Kamdani. 2012. Manajemen Panen Kelapa Sawit (Elaeis guineensis Jacq.) Pada Lahan Gambut Di Kebun Mandah, PT. Bhumireksa Nusa Sejati, Minamas Plantation, Kabupaen Indragiri Hilir, Provinsi Riau. Bogor: Departemen Agronomi Hortikultura Fakultas Pertanian Institut Pertanian Bogor.

Simamora A. W. F,. Sayaketi w.d,. Situmorang A. 2016. Produktivitas Tenaga Kerja Pemanen DI pt. Perkebunan Nusantara vii Unit Kebun Kelapa Sawit Rejosari. http://jurnal.fp.unila.ac.id (diunduh 18 Maret 2021).

Sinungan, Muchdarsyah . 2005 produktivitas: Apa dan Bagaimana. Edisi kedua. Jakarta: Bumi Aksara

Sudarmayanti, M.Pd 2001. Sumber Daya Manusi Dan Produktivitas Kerja. Bandung: Cv. Mandiri Maju. (Skripsi)

Sugiyono. 2015. Metode Penelitian Kuantitatif Deskriptif dan Kualitatif dan R\&D. Afabeta. Bandung.

Sulaiman, A. 2014 "Pengaruh Upah dan Pengalam Kerja Terhadap Produktivitas Karyawan Kerajinan Ukiran:. Jurnal Ekonomi Trikonomika. Vol. 13, No. 1: 1311514

Sunarko. 2014. Budi Daya Kelapa Sawit Di Berbagai Jenis Lahan. Jakarta Selatan: Agro Media Pustaka. 
Sofiana Y., Yahya S. 2015. Manajemen Panen Kelapa Sawit (Elaeis guineensis Jacq.) Di Kebun Tambusai Kec. Tambusai, Kabupaten Rokan Hulu, Riau. Departemen Agronomi dan Hortikultura, Fakultas
Pertanian, Institut Pertanian Bogor. Bul.Agrohorti 2 (3): 213-220 (diunduh 18 maret 2021)

Sulistyo A.I., Bambang. 2010. Budi Daya Kelapa Sawit. Jakarta. Penerbit Balai Penelitian. 